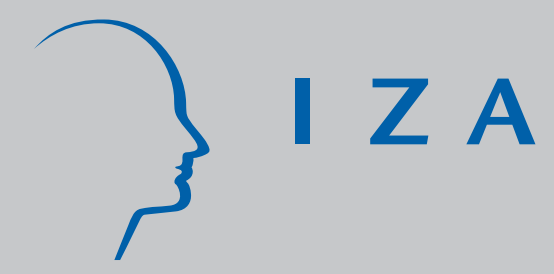

IZADP No. 3331

Ethnic Networks and Employment Outcomes

Eleonora Patacchini

Yves Zenou

February 2008 


\title{
Ethnic Networks and Employment Outcomes
}

\author{
Eleonora Patacchini \\ University of Rome "La Sapienza" \\ and IZA
}

Yves Zenou

Stockholm University, IFN, GAINS

and IZA

Discussion Paper No. 3331

February 2008

\author{
IZA \\ P.O. Box 7240 \\ 53072 Bonn \\ Germany \\ Phone: +49-228-3894-0 \\ Fax: +49-228-3894-180 \\ E-mail: iza@iza.org
}

\begin{abstract}
Any opinions expressed here are those of the author(s) and not those of IZA. Research published in this series may include views on policy, but the institute itself takes no institutional policy positions.

The Institute for the Study of Labor (IZA) in Bonn is a local and virtual international research center and a place of communication between science, politics and business. IZA is an independent nonprofit organization supported by Deutsche Post World Net. The center is associated with the University of Bonn and offers a stimulating research environment through its international network, workshops and conferences, data service, project support, research visits and doctoral program. IZA engages in (i) original and internationally competitive research in all fields of labor economics, (ii) development of policy concepts, and (iii) dissemination of research results and concepts to the interested public.
\end{abstract}

IZA Discussion Papers often represent preliminary work and are circulated to encourage discussion. Citation of such a paper should account for its provisional character. A revised version may be available directly from the author. 
IZA Discussion Paper No. 3331

February 2008

\section{ABSTRACT}

\section{Ethnic Networks and Employment Outcomes}

We analyse the effect of strong and weak ties on the individual probability of finding a job. Using the dynamic model of Calvó-Armengol and Jackson (2004), two results are put forward: $(i)$ the individual probability of finding a job is increasing in the number of strong and weak ties; (ii) the longer the length of ties, the lower is this effect. We approximate the social space by the geographical space. Ethnicity is the chosen dimension along which agents' social contacts develop and, as a result, we use ethnic population density to capture social interactions within the given ethnic group. Using a panel of local authority-level data in England between 1993 and 2003, we find that $(i)$ the higher the percentage of a given ethnic group living nearby, the higher the employment rate of this ethnic group; (ii) this effect decays very rapidly with distance, losing significance beyond approximately 90 minutes travel time.

JEL Classification: A14, C33, J15, R23

Keywords: ethnic minorities, social interactions, population density, weak and strong ties

Corresponding author:

Yves Zenou

Department of Economics

Stockholm University

10691 Stockholm

Sweden

E-mail: yves.zenou@ne.su.se 


\section{Introduction}

Individuals seeking jobs read newspapers, go to employment agencies, browse in the web and mobilize their local networks of friends and relatives. The empirical evidence reveals that around 50 percent of individuals obtain or hear about jobs through friends and family (Granovetter, 1974; Corcoran et al., 1980; Holzer 1988; Montgomery, 1991; Gregg and Wadsworth, 1996; Addison and Portugal, 2001). Such methods have the advantage that they are relatively less costly and may provide more reliable information about jobs compared to other methods. Networks of personal contacts mediate employment opportunities, which flow through word-of-mouth and, in many cases, constitute a valid alternative source of employment information to more formal methods.

Little is known, however, about the importance of social networks across different ethnic groups. In particular, do the kinds of positive effects that have been found for friends and family hold across all ethnic groups in the labor market?

One may think that connections may well be within each own ethnic group in each own area and the effectiveness of these connections may be diminished because of the higher incidence of unemployment amongst ethnic minorities. Having fewer connections to employed individuals makes it more difficult to receive inside information about jobs and reduces the likelihood that one is recommended by current employees to employers.

On the other hand, the hiring of new workers via employee referrals is presumed to be important for understanding ethnic divisions of labor because it creates a built-in bias toward incumbents: members of a particular ethnic group concentrate in particular jobs and when new employment opportunities become available at their workplace, they pass this information along to social contacts, often of the same race and ethnic background.

There is a rich socio-economic literature on patterns of relations among agents documenting that social networks appear to be fairly homogeneous with regard to certain sociodemographic attributes: individuals are likely to associate more with people who are very similar to themselves. This tendency is particularly strong among ethnic groups. A number of papers show that people prefer to associate with others of the same racial or ethnic group (see e.g., Moody, 2001; Topa, 2001; Marmaros and Sacerdote, 2006; Bayer et al., 2007). In particular, using data from the 1985 US General Social Survey, Marsden $(1987,1988)$ analyses the question of assortative matching in social networks. He finds that the strongest level of association, over and above random matching, occurs for the race/ethnicity attribute. Concerning migrants, the received evidence overwhelmingly supports the view that friends and relatives, and particularly those who belong to a common origin-community, are the 
main source of information about jobs (see e.g., Chavez, 1992; Hagan 1994, Menjivar, 2000; Zhou, 1992).

What about the impact of social networks on labor-market outcomes of ethnic minorities? Some evidence can be found in Conley and Topa (2002). They examine the spatial distribution of unemployment in Chicago using different social and economic distance metrics. The results indicate a clear dominance of the racial/ethnic distance metric and of the racial/ethnic composition variables in explaining the spatial correlation of unemployment. More direct evidence can be found in Falcon and Melendez (1996). They show that Latinos in Boston are more likely to use personal networks to gain employment relative to other job search methods. Elliott (2001) finds that Latinos, especially newly arrived immigrants, are more likely than native-born Whites to enter jobs through insider referrals. He also finds that the correlation between insider referrals and ethnically homogeneous jobs is positive and significant only for native-born Blacks. Mouw (2002), using longitudinal data, finds that Black workers who used personal contacts to find employment did no worse compared to where they used formal methods. Munshi (2003) attempts to identify network effects among Mexican migrants in the U.S. labor market and to test whether the network improves labor market outcomes for its members. He finds that the same individual is more likely to be employed and to hold a higher paying nonagricultural job when his network is exogenously larger.

There are, however, very few papers on this issue for Europe. Exceptions include Frijters et. al (2005) and Battu et al. (2005), both for the UK. They find that, though personal networks are a popular method of finding a job for the ethnic minorities and those born outside the UK, they are not necessarily the most effective either in terms of gaining employment or in terms of the level of job achieved.

The aim of the present paper is to focus on ethnic minorities in the UK and to see how social networks improve labor market outcomes for its members, focussing on different issues than that of the above-mentioned papers.

As a theoretical background, we first expose the dynamic model of Calvó-Armengol and Jackson (2004) who explicitly model social networks as graphs. If workers are linked to each other, then they exchange information about jobs. Strong ties are direct friends while weak ties are friends of friends of any length (Granovetter, 1983; Calvó-Armengol et al., 2007; Patacchini and Zenou, 2008). The following results are found. The individual probability of finding a job increases with the number of strong ties and weak ties. However, the longer the length of weak ties, the lower the individual probability of finding a job.

Because we do not have direct information on social interactions between individuals, we 
approximate the social proximity by the geographical proximity, drawing a link between the social and geographical spaces. Since ethnic communities tend to be more socially cohesive, our conjecture is that the density of people living in the same area is a good approximation for the number of direct friends one has, i.e. strong ties, especially if the areas are not too large and if people belong to the same ethnic group. In the same spirit, the density of individuals living in neighboring areas will be a measure of friends of friends, i.e. weak ties. Ethnicity is thus the chosen dimension along which agents' social contacts develop. Consistently with the theoretical model, and given that we control for area-fixed effects, we find that: the higher the percentage of a given ethnic group living nearby, the higher the employment rate of this ethnic group; this effect decays very rapidly with distance, losing significance beyond approximately 90 minutes travel time.

The existing literature on the impact of the spatial concentration of ethnic minorities on labor market outcome is not large, and it presents conflicting results. For the UK, to the best of our knowledge, the available evidence is limited to the studies by Clark and Drinkwater (2000, 2002), which basically document that the poor areas where ethnic minorities live are associated with higher unemployment rates and lower self-employment rates. Their crosssection regression analysis, however, includes only few area-level controls. It is thus well possible that their correlations capture the effects of unobserved area characteristics. In addition, when trying to find evidence of ethnic enclave effects also unobservable area characteristics, such as tastes for discrimination, language difficulties, spatial mistmach effects, are likely to play a fundamental role. On the contrary, using a data from a policy in Sweden that randomly allocates immigrants to their residential location, Edin et al. (2003) find that living in enclaves improves labor-market outcomes for less skilled immigrants. ${ }^{1}$ In our framework, the use of panel data estimation techniques to control for area-fixed effects, and the use of instruments to tackle the sorting problem, allow us to obtain similar results than that of Edin et al. (2003). Because of our theoretical mechanism, we are however able to go further by investigating not only the effect of the concentration of ethnic minorities on employment probabilities in a given area but also in the neighboring areas.

\section{Theoretical analysis}

The aim of our theoretical framework is to understand how strong and weak ties affect the labor-market outcomes of workers. Indeed, given a network structure, we would like to see

\footnotetext{
${ }^{1}$ Using data from Egypt, Wahba and Zenou (2005) show that population density positively affects the individual probablity of finding a job using social networks. They do not however focus on ethnic minorities.
} 
how the size of strong and weak ties affects the individual probability to obtain a job and thus the employment rate in the economy.

For that we expose the model of Calvó-Armengol and Jackson (2004) in which the main problem for each worker is to obtain information about jobs. Each worker is embedded in a network of social relationships, and his/her direct friends are his/her strong ties while the friends of his/her friends of any length are his/her weak ties. This worker can hear about a job either directly (if by chance he/she sees the job advertisement) or indirectly because one of their friends who belongs to their social network is employed, knows about this job and transmits the information to the worker. Observe that it is assumed that the probability to hear directly about a job is the same for someone who is employed and for someone who is unemployed.

\subsection{Some notations and definitions from graph theory ${ }^{2}$}

Denote by $n$ the number of individuals in a given social network $\mathbf{g}$, with $n=U+E$ ( $U$ and $E$ are respectively the unemployment and the employment levels in the network). Therefore $N=\{1, \ldots, n\}$ is a set of individuals connected in some network relationship. A network is thus a list of unordered pairs of players $\{i, j\}$. These links are represented by a graph g, where $g_{i j}=1$ if $i$ is friend with $j$ (denoted by $i j$ ) and $g_{i j}=0$ otherwise (unweighted graphs/networks). In our framework, links are taken to be reciprocal, so that $g_{i j}=g_{j i}$ (undirected graphs/networks). By convention, $g_{i i}=0$. The set of $i$ 's direct contacts is: $N_{i}(\mathbf{g})=\left\{j \neq i \mid g_{i j}=1\right\}$, which is of size $n_{i}(\mathbf{g})$.

One of the key features of networks/graphs is that not only direct but also indirect links that matter.

Definition $1 A$ path of length $k$ from $i$ to $j$ in the network $\mathbf{g} i s$ a sequence $\left\langle i_{0}, i_{1}, \ldots, i_{k}\right\rangle$ of players such that $i_{0}=i, i_{k}=j, i_{p} \neq i_{p+1}$, and $g_{i_{p} i_{p+1}}=1$, for all $0 \leq p \leq k-1$, that is, players $i_{p}$ and $i_{p+1}$ are directly linked in $\mathbf{g}$. If such a path exists, then individuals $i$ and $j$ are path-connected.

In words, a path between two individuals $i$ and $j$ is an ordered set of agents $\left(i, i_{1}, \ldots, i_{k}, j\right)$ of $N$, where an agent can appear several times, such that $i \neq j$. We say that a path belongs to the network $\mathbf{g}$ if $g_{i i_{1}} g_{i_{1} i_{2}} \ldots g_{i_{k} j} \neq 0$.

To summarize:

\footnotetext{
${ }^{2}$ For a more complete overview of these definitions, see Wasserman and Faust (1994) and Jackson (2008).
} 
Definition 2 An individual $i$ holds a strong tie with an individual $j$ if $g_{i j}=1$. An individual $i$ holds a weak tie with an individual $j$ if individuals $i$ and $j$ are path-connected. The length $k$ of this (weak) tie is defined by the length of the path between individuals $i$ and $j$.

\subsection{The model}

We now describe the model of Calvó-Armengol and Jackson (2004). Time evolves in discrete periods indexed by $t$. The vector $s_{t}$ describes the employment status of the workers at time $t$. If individual $i$ is employed at the end of period $t$, then $s_{i t}=1$ and if $i$ is unemployed then $s_{i t}=0$.

A period $t$ begins with some agents being employed and others not, as described by the status $s_{t-1}$ from the last period. Next, information about job openings arrives. In particular, any given individual hears about a job opening with a probability $a$ that is between 0 and 1 . This job arrival process is independent across individuals. If the individual is unemployed, then he/she will take the job. However, if the individual is already employed then he/she will pass the information along to a friend, picked at random among his/her unemployed friends. As stated above, graph or network $\mathbf{g}$ summarizes the links of all agents, where $g_{i j}=1$ indicates that $i$ and $j$ know each other (strong tie), and share their knowledge about job information, while $g_{i j}=0$ indicates that they do not know each other.

Observe that if an employed worker hears about a job but all his/her friends (i.e. direct links) are already employed, then the job is lost. We focus here on a model where wages are exogenous and identical for all workers. So there is no room in this model for an employed worker to exploit a job offer to increase his/her current wage.

Finally, the last thing that happens in a period is that some agents lose their jobs. This happens randomly according to an exogenous breakup rate, $\delta$, between 0 and 1 . We are able to write the probability $\mathbb{P}_{i j}$ of the joint event that individual $i$ learns about a job and this job ends up in individual $j$ 's hands. It is equal to:

$$
\mathbb{P}_{i j}(\mathbf{s})=\left\{\begin{array}{ccc}
a & \text { if } & s_{i}=0 \text { and } i=j \\
a / \sum_{k: s_{k}=0} g_{i k} & \text { if } & s_{i}=1, s_{j}=0, \text { and } g_{i j}=1 \\
0 & & \text { otherwise }
\end{array}\right.
$$

where the vector $\mathbf{s}$ describes the employment status of all the individuals at the beginning of the period. In (1), $a$ is the probability to obtain a job information without using friends and relatives. Three cases may then arise. If individuals $i$ and $j$ are unemployed $\left(s_{i}=s_{j}=0\right)$, then the probability that $j$ will obtain a job is just $a$ since individual $i$ will never transmit any information to $j$. If individual $i$ is already employed and his/her friend $j$ is not $\left(s_{i}=1\right.$, 
$s_{j}=0$ ), then individual $i$ transmits this job information to all his/her direct unemployed neighbors, who total number is $\sum_{k: s_{k}=0} g_{i k}$. We assume that all unemployed neighbors are treated on equal footing, meaning that the employed worker who has the job information does not favor any of his/her direct neighbors. As a result, the probability that an unemployed worker $j$ is selected among the $\sum_{k: s_{k}=0} g_{i k}$ unemployed direct neighbors of an employed worker $j$ is given by: $a / \sum_{k: s_{k}=0} g_{i k}$. Finally, if individual $j$ is employed, then he/she does not need any job information, at least in the current period.

\subsection{Impact of strong ties on employment probabilities}

The first result obtained by Calvó-Armengol and Jackson (2004) is not surprising and has also been showed in a static framework (see Calvó-Armengol, 2004, and Calvó-Armengol and Zenou, 2005).

Proposition 1 The higher $n_{i}(\mathbf{g})$, the number of strong ties individual $i$ has, the higher his/her individual probability of obtaining a job.

Indeed, if an individual has more strong ties, then he/she is more likely to hear on average about more jobs through his/her friends and relatives but his/her chance to find a job directly does not increase since $a$ is not affected by the size of the network. This result is quite intuitive since when the number of direct connections increases, the source of information about jobs is larger and people find it more easy to obtain a job through their friends and relatives. This is the first prediction of the model, which implies that workers have a greater chance to find a job the higher the number of their strong ties. Observe that the individual probability to find a job through strong ties for individual $j$ is obviously not given by (1) since $\mathbb{P}_{i j}(\mathbf{s})$ is the probability that only one individual, $i$, who hold a strong tie with $j$, and who is aware of some job, will transmit this information to individual $j$. To determine the individual probability of obtaining a job for $j$, one has to do the calculation for all the direct friends of $i$.

\subsection{Impact of weak ties on employment probabilities}

We would like now to study the impact of weak ties (as defined by Definition 1) on the individual probability of finding a job. Calvó-Armengol and Jackson (2004) show that, in steady-state, there is a positive correlation in employment status between two path-connected workers. As we will see, this result is not at all easy to obtain since, in the short run, the correlation is negative. Indeed, in a static model, if an employed worker is directed linked 
to two unemployed workers, then if he/she is aware of a job, he/she will share this job information with his/her two unemployed friends (see (1)). These two persons, who are path-connected (path of length two) are thus in competition and one (randomly chosen) will obtain the job and be employed while the other will stayed unemployed. So their employment statuses will be negatively correlated (see Calvó-Armengol, 2004, and Calvó-Armengol and Zenou, 2005).

Let us now give the intuition why this negative correlation result does not hold in a dynamic labor-market model. Consider the star-shaped network described in Figure 1 with three individuals, i.e. $n=3$ and $g_{12}=g_{23}=1$. Suppose the employment from the end of the last period is $\mathbf{s}_{\mathbf{t}-\mathbf{1}}=(0,1,0)$. In the figure, a black node represents an employed worker (individual 2), while unemployed workers (1 and 3) are represented by white nodes. Conditional on this state $\mathbf{s}_{\mathbf{t}-\mathbf{1}}$, the employment states $s_{1 t}$ and $s_{3 t}$ are negatively correlated. As stated above, this is due to the fact that individuals 1 and 3 are "competitors" for any job news that is first heard by individual 2 .

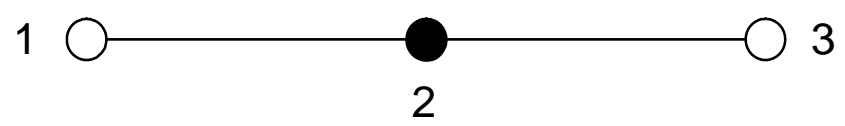

Figure 1. Employment correlations in a star-shaped network

Despite this negative (conditional) correlation in the shorter run, individual 1 can benefit from individual 3's presence in the longer run. Indeed, individual 3's presence helps improve individual 2's employment status. Also, when individual 3 is employed, individual 1 is more likely to hear about any job that individual 2 hears about. These aspects of the problem counter the local (conditional) negative correlation, and help induce a positive correlation between the employment status of individuals 1 and 3 .

In what follows, we describe how we obtain this long-run positive correlation. Consider again the network described in Figure 1 but without imposing any employment status to workers. In that case, there are eight possible employment states: 000, 100, 010, 001, 110, 101, 011, 111, where for example 000 means that all individuals 1, 2, and 3 are unemployed. As a result, the state of the economy $s_{t}$ evolves following a Markov process $\mathcal{M}(a, \delta)$ where $a$ is the job-arrival rate that takes place in the first half of each period, while $\delta$ is the job-destruction rate that takes place at the second half of each period. We gather the Markov transitions into a matrix $\mathbb{P}_{i j}=\operatorname{Pr}\left\{s_{t+1}=i \mid s_{t}=j\right\}$, where $i, j \in\{000,100,010,001,110,101,011,111\}$, that is, rows correspond to $t+1$ while columns correspond to $t$ (the columns sum up to one 
as in all Markov matrices).

As highlighted above, an important issue in this case is the short-run negative correlation versus the long-run (possibly) strictly positive correlation. To sort out the short and longer run effects, we divide $a$ and $\delta$ both by some larger and larger factor, so that we are looking at arbitrarily short time periods. We call this the "sub-division" of periods. More precisely, instead of analyzing the Markov process $\mathcal{M}(a, \delta)$, we can analyze the associated Markov process $\mathcal{M}(a / T, \delta / T)$, that we name the $T$-period subdivision of $\mathcal{M}(a, \delta)$, with steady state distribution $\mu^{T}$. We show that there exists some $T^{\prime}$ such that, for all $T \geq T^{\prime}$, the employment statuses of any path-connected agents are positively correlated under $\mu^{T}$. Consider $\mathcal{M}(a / T, \delta / T)$. For this Markov process, at every period, every shock (be it a job arrival $a / T$ or a job breakdown $\delta / T)$ is very unlikely when $T$ is high enough. Having two or more shocks in every such period is thus much less unlikely. Instead of analyzing $\mathcal{M}(a / T, \delta / T)$, we analyze an approximated Markov process $\mathcal{M}^{*}(a / T, \delta / T)$ where we only keep track of one-shock transitions, and disregard transitions involving two or more shocks. We denote by $\mu^{* T}$ the corresponding steady-state distribution. The higher $T$, the closer are the transitions of the approximated Markov process $\mathcal{M}^{*}(a / T, \delta / T)$ to that of the true Markov process $\mathcal{M}(a / T, \delta / T)$, and so the closer is $\mu^{* T}$ to $\mu^{T}$.

Calvó-Armengol and Jackson (2004) show that, with a high enough $T$-period subdivision, for $n$ individuals and any social network structure, we have:

Proposition 2 Under fine enough subdivisions of periods, the unique steady-state long-run distribution on employment is such that the employment statuses of any path-connected agents are positively correlated.

The proposition shows that despite the short-run conditional negative correlation between the employment of competitors for jobs and information, in the longer run any interconnected workers' employment is positively correlated. This implies that there is a clustering of agents by employment status, and employed workers tend to be connected with employed workers, and vice versa. The intuition is clear: conditional on knowing that some set of agents are employed, it is more likely that their neighbors will end up receiving information about jobs, and so on. The benefits from having other agents in the network outweigh the local negative correlation effects, if we take a long-run perspective.

Proposition 3 The longer the length of two-path connected individuals (i.e. weak ties), the lower is the correlation in employment statuses between these two individuals. 
Indeed, the correlation between two agents' employment is (weakly) decreasing in the number of links that each an agent has, and the correlation between agents' employment is higher for direct compared to indirect connections. The decrease as a function of the number of links is due to the decreased importance of any single link if an agent has many links. The difference between direct and indirect connections in terms of correlation is due to the fact that direct connections provide information, while indirect connections only help by indirect provision of information that keeps friends, friends of friends, etc., employed. In other words, the longer the path in the social network between two individuals, the weaker is the effect of job transmission.

\section{Empirical analysis}

Let us summarize our theoretical results. We have shown that:

(i) The individual probability of finding a job is increasing in the number of strong ties each individual has (Proposition 1);

(ii) The individual probability of finding a job is increasing in the number of weak ties each individual has (Proposition 2);

(iii) The longer the length of weak ties, the lower the individual probability of finding a job (Proposition 2).

We would now like to test these results.

\subsection{Empirical strategy}

Because individual data on social networks and friendships are not available, we will approximate the social proximity by the geographical proximity, drawing a link between the social and geographical spaces. Our conjecture is that the density of people living in the same area is a good approximation of the number of direct friends one has, i.e. strong ties, especially if the areas are not too large and if people belong to the same ethnic group (Topa, 2001). In the same spirit, the density of individuals living in neighboring areas will be a measure of friends of friends, i.e. weak ties. Using this approach, the theoretical predictions are as follows.

Take an individual with a given set of characteristics (family, age, education, gender...), living in area $a$ and belonging to race $r$. Then, other things being equal (i.e. fixing the characteristics of the area): 
(i) Individual $(a, r)$ has a higher chance to be employed, the higher the percentage of type $-r$ individuals living in area $a$.

(ii) Individual $(a, r)$ has a higher chance to be employed, the higher the percentage of type $-r$ individuals living in the neighboring areas of $a$.

(iii) This effect should decrease with the distance between area $a$ and its neighboring areas.

The aim of our empirical analysis is to test these three predictions $(i),(i i)$, and (iii). Because longitudinal individual-level data on ethnic minorities with information on the residential area are not available, we resort to the use of aggregate data, which are described in the following section.

\subsection{Data and definition of the variables}

Our empirical analysis is based on a panel of local authority-level data in England from 1993 until 2003. The data source is the UK Labour Force Survey (LFS), which is undertaken on a quarterly basis (since 1992). However, because of small sample sizes per area for ethnic minority groups, we aggregate the quarterly data of each year, so to end up with ten waves of the panel. ${ }^{3}$

The local authority is the finer level of spatial disaggregation of the English local government structure. In England, there is indeed a mix of single-tier and two-tier local government. Our definition of "local authority" considers single-tier (unitary) authorities together with the lower-tier authorities in areas of two-tier local government. We thus deal with small spatial units, having an average of 2,250 residents belonging to ethnic minorities. In London there are 33 local authorities (London boroughs). Excluding areas with missing or incomplete information on our target variables (roughly the $15 \%$ of the total), we are left with a final sample of 301 local authorities in England.

We measure distance between areas by the average road journey time (in minutes) between the centres of the areas. ${ }^{4}$ Indeed, driving times represents how agents' contacts develop better than other measures of proximity, such as physical distance or contiguity (see, e.g.

\footnotetext{
${ }^{3}$ The LFS data is available through the Office of National Statistics (ONS). The yearly figures for the years 1999-2003 at the local authority-level are also available on-line from the National On-line Manpower Information Service (NOMIS) located at the University of Durham.

${ }^{4}$ Distances in travel times and kilometers are estimated using Microsoft Autoroute 2002. The Microsoft Autoroute software computes the driving time between two locations on the basis of the most efficient route given the road network in 2002, and allowing for different average speeds of travel depending on the type of road.
} 
Conley and Topa, 2002). The estimated road journey time between areas in the sample varies between 9.7 minutes and 514 minutes, with a mean journey time of approximately 198 minutes.

We distinguish between different ethnic groups. Whites, Blacks (Black Caribbeans, Black African-Asians and Black British), Asians (Indians, Pakistanis and Bangladeshis), and Chineses. ${ }^{5}$ The ethnicity is captured by the index $r=B, A, C$, respectively. Because of the extremely low activity rates of women in certain ethnic groups (most notably Pakistani and Bangladeshi women), we focus our attention on males. ${ }^{6}$

The individual probability of finding a job of individual of type $-r$ in local authority $a$ is measured using the ratio between the number of type- $r$ employed workers in local authority $a$ and the total working age population of type $-r$ individuals residing in local authority $a$ (i.e., the employment rate of ethnic minorities of type $r$ living in local authority $a, e_{a}^{r}$, hereafter).

The group $-r$ population density in local authority $a$ is the ratio between the total working age population of group $r$ residing in local authority $a$ and the total working age population residing in local authority $a$.

Figures 2 and 3 describe the evolution over time of our two target variables, i.e. employment rate and population density. Specifically, the figures plots the average (over all areas in our sample) employment rate and population density for each time period available, for the different groups within the nonwhite population, i.e. Black, Asian and Chinese. ${ }^{7}$

\section{[Insert Figures 2 and 3 here]}

Figure 2 shows that employment rates have increased over time for virtually all minority ethnic groups. Asians have experienced the largest increase, followed by Chinese and finally Blacks. During the same period of time, Figure 3 shows that the density of ethnic population has also increased over time. For example, taking into account all nonwhites as a whole, the average population density has risen from $0.6 \%$ in 1993 to $1.33 \%$ in 2003. This implies that, in 1993, there were 1 nonwhite every 167 individuals, whereas, in 2003, this ratio is roughly 1 to 76 . Indeed, the increase in the number of individuals from different ethnic groups is one of the most significant changes in Britain during the 1990s. According to Census data, Britain's population grew by $4 \%$ in the $1990 \mathrm{~s} ; 73 \%$ of this growth was due to minority ethnic groups, which grew by about 1.6 million people compared with 600,000 in the white

\footnotetext{
${ }^{5}$ Small sample sizes for each areas prevent us to adopt a finer breakdown by ethnicity.

${ }^{6}$ In Section 5, the analysis is also performed for females.

${ }^{7}$ The sum of the values of the different ethnic minority groups is not equal to the value of nonwhites because there is a (small) residual groups, i.e. "other races", which is not considered here.
} 
population (Lupton and Power, 2004). Increasing values of ethnic population density over time are consistent with a pattern of natural population growth as well as with immigration inflows in areas having already sizeable minority ethnic population. Under both scenarios, however, this evidence show that, in England, ethnic minorities are geographically clustered.

Turning back to the definition of the remaining variables, in the theoretical model, the length of ties is measured by the path connecting individuals (see definitions 1 and 2). Since we approximate the social space by the physical space, to measure ties of different lengths we create proximity bands based on driving time between areas and we measure the population density by ethnic group within each proximity band. To be specific, for each local authority $a$ in our sample, we create new variables containing the densities of ethnic population within 30 minutes driving time from local authority $a$; within 30-60 minutes, and so on. We assume that the population of each local authority is concentrated at the economic centre of the local authority, so that each time band (e.g., 30-60 minutes) contains the population densities of all areas whose centre is in the band (e.g., within 30-60 minutes from the centre of local authority $a){ }^{8}$

Thus, for each individual belonging to ethnic group $r$ and residing in local authority $a$, the percentage of strong ties will be measured by the population density of ethnic group $r$ living within 30 minutes and his/her percentage of weak ties as the population density of ethnic group $r$ living further away. The longer the geographical distance between local authority $a$ and the neighboring local authorities, the longer the social distance or equivalently the length of weak ties between individuals.

\section{Empirical model and estimation results}

Consistently with the dynamic theoretical model presented in Section 2, for each ethnic group $r=B, A, C$ we estimate the following dynamic panel regression model:

$$
e_{a, t}^{r}=\alpha e_{a, t-1}^{r}+\sum_{\sigma} \gamma_{\sigma}^{r} n_{\sigma, a, t}^{r}+\eta_{a}+\varepsilon_{a, t}^{r}, \quad|\alpha|<1, \quad a=1, \ldots, N ; t=2, \ldots, T
$$

where $e_{a, t}^{r}$ is the employment rate of ethnic group $r$ in local authority a at time $t, e_{a, t-1}^{r}$, the same variable at time $t-1$, and $n_{\sigma, a, t}^{r}$ denotes the population density of ethnic group $r$ in local authority $a$ within the proximity bands $\sigma$ at time $t$. The error term is composed

\footnotetext{
${ }^{8}$ The analysis has also been performed assuming that the population is evenly distributed within the area (see, Rosenthal and Strange, 2006 and Rice and al., 2006, for details on this approach). The results remain qualitatively unchanged.
} 
of an area-specific fixed effect, $\eta_{a}$, controlling for cross-area differences constant across time and by a white noise error component, $\varepsilon_{a, t}^{r}$. Observe that the empirical model does neither include any measure of the average human capital characteristics of the different areas, nor other features of the local structure of the economy (such as the activity rate for example). Indeed, we assume that the impact of these characteristics on the employment rate in each area is captured through the inclusion of (time) lagged values of the employment rate $e_{a, t-1}^{r}$. In other words, we use area-fixed effects to purge our estimates from the effects of area characteristics that are constant over time and we assume that the impact of time-varying variables on the employment rate in each location is captured through the inclusion of (time) lagged values of the employment rate. ${ }^{9}$

The conjecture underlying the specification of this empirical model is that the social and geographical spaces should be correlated for individuals within the same ethnicity, and more so given that our areas (local authorities) are quite small. As it is also documented in the introduction, it is very likely that, for example, blacks communicate with the other black persons living nearby. Therefore, the higher the percentage of blacks living nearby, the more information about jobs is provided This is not necessarily true for whites. Marsden (1988) shows, for instance, that the chance of observing a black-black tie is 4.2 times higher than that generated by pure random matching, whereas this value is only 2.6 for whites. Thus, a comparison of the estimation results of model (2) for whites and nonwhites may provide valuable insights about the validity of our approach.

\subsection{OLS estimates}

Model (2) is estimated for whites and each ethnic group separately. Table 1 reports the results obtained with five proximity bands: up to $30 \mathrm{~min}, 30$ to $60 \mathrm{~min}, 60$ to $90 \mathrm{~min}, 90$ to $120 \mathrm{~min}, 120$ to $150 \mathrm{~min}$. The table contains the within groups estimates, i.e. OLS where all variables are expressed in deviations from their area-specific means (taken over time) for the model without (first column) and with (second column) regional dummies. ${ }^{10}$

If we compare the results for whites with those for the other ethnic minorities, it appears that the density of white population has no significant effect on white employment, whereas

\footnotetext{
${ }^{9}$ However, the inclusion of a list of contemporary area-specific controls, such as proportion of high-skilled population, proportion of car owners, unemployment rate by ethnic group, white and nonwhite population mass, etc.., does not change qualitatively the results on our target variables.

${ }^{10}$ As $T$ becomes large, the within groups estimator is consistent, even in the presence of lagged dependent variables (or other endogenous regressors). Thus, with our panel of 10 years time-length, any bias from using within groups is likely to be minimal (see Nickell, 1981, for example).
} 
the density of ethnic population shows a significant effect on ethnic employment for all the ethnic minorities' groups. In addition, the specification for whites is less well-determined (the $R$-squared values for nonwhites are roughly twice as large as for whites). This confirms the intuition we had when we approximated the social with the geographical space. Indeed, for whites, the percentage of whites living nearby is not a good measure of social interactions between whites. On the contrary, for nonwhites, it is a much better measure since it is more likely that nonwhites interact with each other by providing job information within the same and neighboring local authorities.

\section{[Insert Table 1 here]}

Focusing on the estimates of the spatial decay for the different ethnic minorities, we find positive and statistically significant effects, which are greatest within 30 minutes driving time. They then decrease quite sharply with travel time and have no effect beyond approximately 90 minutes. This pattern remains unchanged across the different ethnic minority groups. If we go back to our theoretical model, then this means that strong ties (i.e. population density of the same ethnic group within 30 minutes driving time) have a greater positive impact on the employment rate than weak ties of length 2 (i.e. population density of the same ethnic group within 30 to 60 minutes driving time), which, in turn, has a higher impact than weak ties of length 3 (i.e. population density of the same ethnic group within 60 to 90 minutes driving time), etc.

The magnitude of the effects is also quite similar across ethnic groups, displaying however the highest values as well as the highest rate of attenuation for Asians. Indeed, a one point percentage increase in the density of the Asian population within 30 minutes driving time increases Asian employment rate by roughly 0.10 percentage points. It has more than three times the impact of the density of the Asian population 60 minutes away, and more than 10 times that of the density of the Asian population at 90 minutes.

\subsection{Instrumental variable estimates}

If areas that attract ethnic population have also exogenously determined characteristics (not directly observable) that affect employment, then the population density variables will be correlated with the error term. In other words, there may be some sorting of the population where ethnic minorities choose to live in areas mainly populated by individuals belonging to the same ethnic group. In that case, instead of social networks, we may capture some unobserved characteristics of workers if, for example, the higher the (unobserved) ability of 
ethnic minorities, the more likely they live in areas with the highest population density of the same ethnic group.

In our analysis, the adoption of a panel data estimator with area fixed effects removes any unobserved area characteristic constant over time, which could be responsible for such a sorting behavior. It does not account, however, for the effects of a possible endogenous sorting of a different nature. As it is standard, we address this problem by using an instrumental variable approach. For each area, we instrument the actual population with the historical population as reported in the 1961 Census. The validity of these instruments rests on the assumption that the location decisions of the ethnic population more than forty years ago are unrelated to the (unobserved) factors determining employment activity today, apart from their effect through present-day ethnic population.

We employ the Arellano and Bond (1991) instrumental variable estimator for dynamic panel data. This method consists in taking deviations from the area-specific time means to get rid of the unit-specific error term and combining valid instruments for the lagged dependent variable and for the other endogenous variables in a GMM framework. Distributional assumptions are not needed. Given the first order autoregressive specification of our model, valid instruments for the (time) lagged dependent variable are two-time or more periods lagged variables. The Sargan test of overidentifying restrictions (Sargan, 1958) is used to choose the appropriate set of instruments, and, in particular, the number of lags of the dependent variable to be included in the instrumental set. Our instrumental variable estimates for the basic specification with regional dummies are reported in Table 2. ${ }^{11}$ The Sargan test does not reject the null of instruments' validity. In the last rows, we also report tests for first-order and second-order serial correlation in the first-differenced residuals $\left(\mathrm{M}_{-} 1\right.$ and M_2 ). The consistency of the GMM estimators requires the absence of serial correlation in the original error term. In turn, this requires negative first-order, but no second-order correlation in the differenced error term. Table 2 reveals no evidence of misspecification. The results confirm the main findings of Table 1 . The estimated effects are only slightly higher in magnitude.

\section{[Insert Table 2 here]}

\footnotetext{
${ }^{11}$ To save space, in Table 2, we only give the results when the regional dummies are included.
} 


\section{Discussions and robustness checks}

\subsection{Discussions}

Because we have area-fixed effects, which account for unobserved area heterogeneity constant over time, one could argue that the ethnic population density variable is picking up some neglected area characteristics that vary over time. This is, however, not credible because the areas where ethnic minorities are mostly concentrated are in general quite disadvantaged and the characteristics of such areas are typically associated with lower rather than better prospects of finding a job. In our analysis, on the contrary, we find a positive sign.

Another concern could be that population density is capturing the degree of urbanization of the area instead of social interactions. In that case, an alternative explanation would be that, in denser areas, there are relatively more jobs than in less populated areas so that the chance to find a job also increases. If this were true, then how can we explain that the positive relationship between employment rate and population density is only valid for nonwhites and not for whites? Why white workers would not benefit from better job opportunities in denser areas?

\subsection{More intuition of our results}

In order to better understand our mechanism, we would like now to investigate further our relationship between ethnic population density (capturing social networks and transmission of job information) and ethnic employment probabilities by looking at certain aspects of it. First, because ethnic minorities tend to be more self-employed than whites, we will see if our relationship is stronger or weaker for self-employed workers only. Second, because ethnic minorities tend to concentrate in specific jobs (or industries), we will investigate if our relationship is stronger in certain activities, i.e. information transmission is better in certain jobs. Finally, because ethnic minorities have different cultures and traditions concerning female work participation, we will also examine the relationship between ethnic population density and ethnic employment probabilities for female only.

Let us start with self-employment. Figure 4 displays the evolution of ethnic self-employment over time. Consistently with the definition of employment rate, self-employment rate is calculated as the proportion of all those in working age (excluding students) who are selfemployed. Thus, the values plotted in Figure 4 are a portion of those represented in Figure 2. A comparison between these two figures shows to what extent the dynamics of the employment rates are attributable to changes in self-employment over time for the different ethnic 
groups. Figure 4 shows very large variations in self-employment rates among the different ethnic populations, with the Chinese group having the higher rates, followed by Asians and Blacks. Even though this ranking remains the same over the period 1993-2003, ethnic differences have narrowed over time: Asians and Chineses, which have higher self-employment rates in 1993, experienced a decline, while Black with initially a lower rate showed a slight increase. Having in mind Figure 2, it appears, however, that the marked increase in ethnic employment is not driven by the dynamics of self-employment for any ethnic group.

\section{[Insert Figure 4 here]}

Table 3 reports the estimation results for model (2) for self-employment only. The results remain qualitatively unchanged but the estimated effects are smaller in magnitude for all ethnic groups and at all distance bands. This could be explained by the fact that finding a job requires social networks, especially for ethnic minorities, while for self-employment this is still true but to a lesser extent.

\section{[Insert Table 3 here]}

Let us now investigate the relationship between ethnic population density and ethnic employment probabilities for different types of jobs. Table 4 provide simple statistics of the structure of employment and self-employment by ethnic group and by industry. It gives both average values and the percentage-point changes over the ten years considered. Not surprisingly, in 2003, roughly half of the Chineses and Asians were employed in the "distribution, hotel and restaurant" industry. These figures are even higher for self-employment. On the contrary, blacks seem to be more spread, even though most of them work within the service sector $(20.9 \%$ of then work in the "distribution, hotel and restaurant" industry, $21.3 \%$ in the "banking, finance and insurance" category and $28.5 \%$ in "other" category, which includes mainly public administration, education or health sector). Interestingly, the share of ethnic minorities employed in the "banking, finance and insurance" sector increases over time. Indeed, between 1993 and 2003, its share increased for all ethnic groups, in particular for Blacks in self-employment where we find a $12 \%$ increase in ten years.

\section{[Insert Table 4 here]}

Table 5 displays the results obtained from the estimation of model (2) when employment is disaggregated by industry for whites and nonwhites. To save place, we report the results only 
for the nonwhite population, which groups all ethnic groups together. ${ }^{12}$ As before, the results are significant for nonwhites and not for whites. Concerning nonwhites, in accordance with Table 4, the coefficients are larger in magnitudes for the "distribution, hotel and restaurant" and "banking, finance and insurance" sectors. This means that the transmission of job information and thus ethnic social networks have a larger effect in these sectors than in others. If one compares the distance decay across industries, we find that for the "distribution, hotel and restaurant" sector, the effect fades away after 60 minutes, whereas for the "banking, finance and insurance" sector, it is still significant at distances within 90-120 minutes. This shows that social networks are more localized for the former than for the latter sector.

\section{[Insert Table 5 here]}

We investigate finally the role of importance of women in social networks. In other words, we estimate model (2) for female employment only. Table 6 collects the evidence. It is striking to see that the estimated effects are not statistically significant for all groups (whites and nonwhites). This is not surprising because there are fewer females and the channel through which job information is transmitted is usually between men.

$$
\text { [Insert Table } 6 \text { here] }
$$

\section{Conclusion}

In this paper, we test whether ethnic networks improve labor market outcomes for its members. We first present a simplified version of the model of Calvó-Armengol and Jackson (2004), which shows that the individual probability of finding a job increases with the number of strong ties and weak ties, and the longer the length of weak ties, the lower this probability. We then test these predictions using a panel of local authority-level data in England between 1993 and 2003. Conjecturing that the social space is highly correlated to the physical space, especially for ethnic minorities in small areas, we find that the higher the percentage of a given ethnic group living nearby, the higher the employment rate of this ethnic group. However, this effect decays very rapidly with distance, losing significance beyond approximately 90 minutes travel time.

\footnotetext{
${ }^{12}$ We have also performed the same regression analysis for each ethnic group separately and find the same qualitative evidence. This analysis has also been performed for self-employment only. The results remain qualitatively unchanged. They are typically lower in magnitude, in accordance to Table 3.
} 


\section{References}

[1] Addison J.T. and P. Portugal (2002), "Job search methods and outcomes," Oxford Economic Papers 54, 505-533.

[2] Arellano, M. and S. Bond (1991), "Some test of specification for panel data: Monte Carlo evidence and an application to employment equations," Review of Economic Studies 58, 277-297.

[3] Battu, H., Seaman, P.T., and Y. Zenou (2005), "Job contact networks and the ethnic minorities," CEPR Discussion Paper No. 5225.

[4] Bayer, P., F. Ferreira, and R. McMillan (2007), "A unified framework for measuring preferences for schools and neighborhoods," Journal of Political Economy 115, 588-638.

[5] Calvó-Armengol, A. (2004), "Job contact networks," Journal of Economic Theory 115, 191-206.

[6] Calvó-Armengol, A. and M.O. Jackson (2004), "The effects of social networks on employment and inequality," American Economic Review 94, 426-454.

[7] Calvó-Armengol, A., Verdier, T. and Y. Zenou (2007), "Strong and weak ties in employment and crime," Journal of Public Economics 91, 203-233.

[8] Calvó-Armengol, A. and Y. Zenou (2005), "Job matching, social network and word-ofmouth communication," Journal of Urban Economics 57, 500-522.

[9] Chavez, L. (1992), Shadowed Lives: Undocumented Immigrants in American Society, New York: Harcourt Brace Jovanovich College Publishers.

[10] Clark, K. and S. Drinkwater (2000), "Pushed out or pulled in? Ethnic minority selfemployment in England and Wales," Labour Economics 7, 603-628.

[11] Clark, K. and S. Drinkwater (2002), "Enclaves, neighbourhood effects and economic activity: Ethnic minorities in England and Wales," Journal of Population Economics $15,5-30$.

[12] Conley, T.G. and G. Topa (2002), "Socio-economic distance and spatial patterns in unemployment," Journal of Applied Econometrics 17, 303-327. 
[13] Corcoran, M., Datcher, L. and G.J. Duncan (1980), "Most workers find jobs through word of mouth," Monthly Labor Review 103, 33-35.

[14] Doornik, J.A. (2001), Object-Oriented Matrix Programming Using Ox, 4th edition, London: Timberlake Consultants Press.

[15] Edin, P.-A., Fredriksson, P. and O. Åslund (2003), "Ethnic enclaves and the economic success of immigrants. Evidence from a natural experiment," Quarterly Journal of Economics 118, 329-357.

[16] Elliott, J.R. (2001), "Referral hiring and ethnically homogeneous jobs: How prevalent is the connection and for Whom?" Social Science Research 30, 401-425.

[17] Falcon, L.M and E. Melendez (1996), "The role of social networks in the labor market outcomes of Latinos, Blacks and Non-Hispanic Whites", Paper presented at the Russell Sage Foundation Conference on Residential Segregation Social Capital and Labor Markets, New York.

[18] Frijters, P. Shields, M.A. and S. Wheatley-Price (2005), "Immigrant job search in the UK: Evidence from panel data," Economic Journal 115, F359-F376.

[19] Granovetter, M. (1974), Getting a Job, Chicago: University of Chicago Press.

[20] Granovetter, M.S. (1983), "The strength of weak ties: A network theory revisited", Sociological Theory 1, 201-233.

[21] Gregg, P. and J. Wadsworth (1996), "How effective are state employment agencies? Jobcentre use and job matching in Britain," Oxford Bulletin of Economics and Statistics $58,443-457$.

[22] Hagan, J.M. (1994), Deciding to be Legal: A Maya Community in Houston, Philadelphia: Temple University Press.

[23] Holzer, H.J. (1988), "Search method use by the unemployed youth," Journal of Labor Economics 6, 1-20.

[24] Jackson, M.O. (2008), Social and Economic Networks, Princeton: Princeton University Press, forthcoming.

[25] Lupton, R. and A. Power (2004), "Minority ethnic groups in Britain," Centre for Analysis of Social Exclusion, Case-Brookings Census Briefs No.2, London. 
[26] Marmaros, D. and B. Sacerdote (2006), "How do friendships form," Quarterly Journal of Economics 121, 79-119.

[27] Marsden, P.V. (1987), "Core discussion networks of Americans," American Sociological Review 52, 122-131.

[28] Marsden, P.V. (1988), "Homogeneity in confiding relations," Social Networks 10, 57-76.

[29] Menjivar, C. (2000), Fragmented Ties: Salvadoran Immigrant Networks in America, Berkeley: University of California Press.

[30] Montgomery, J. (1991), "Social networks and labor-market outcomes: Toward an economic analysis," American Economic Review 81, 1408-1418.

[31] Moody, J. (2001), "Race, school integration, and friendship segregation in America," American Journal of Sociology 107, 679-716.

[32] Mouw, T. (2002), "Racial differences in the effects of job contacts: Conflicting evidence from cross-sectional and longitudinal data," Social Science Quarterly 31, 511-538.

[33] Munshi, K. (2003), "Networks in the modern economy: Mexican migrantsin the U.S. labor market," Quarterly Journal of Economics 118, 549-599.

[34] Nickell, S. (1981), "Biases in dynamic models with fixed effects," Econometrica, 49, 1417-26.

[35] Patacchini, E. and Y. Zenou (2008), "The strength of weak ties in crime," European Economic Review, forthcoming.

[36] Rice, P., Venables A.J. and E. Patacchini (2006), "Spatial determinants of productivity: Analysis for the regions of Great Britain," Regional Science and Urban Economics 36, 727-752.

[37] Rosenthal S.S. and W. Strange (2006), "The attenuation of human capital spillovers," Unpublished manuscript, Syracuse University.

[38] Sargan, J. D. (1958), "The estimation of economic relationships using instrumental variables," Econometrica 26, 393-415.

[39] Topa, G. (2001), "Social interactions, local spillovers and unemployment," Review of Economic Studies 68, 261-295. 
[40] Wahba, J. and Y. Zenou (2005), "Density, social networks and job search methods: Theory and applications to Egypt," Journal of Development Economics 78, 443-473.

[41] Wasserman, S. and K. Faust (1994), Social Network Analysis: Methods and Applications, Cambridge: Cambridge University Press.

[42] Zhou, M. (1992), Chinatown: The Socioeconomic Potential of an Urban Enclave, Philadelphia: Temple University Press. 
Figure 2. The evolution of ethnic employment over time

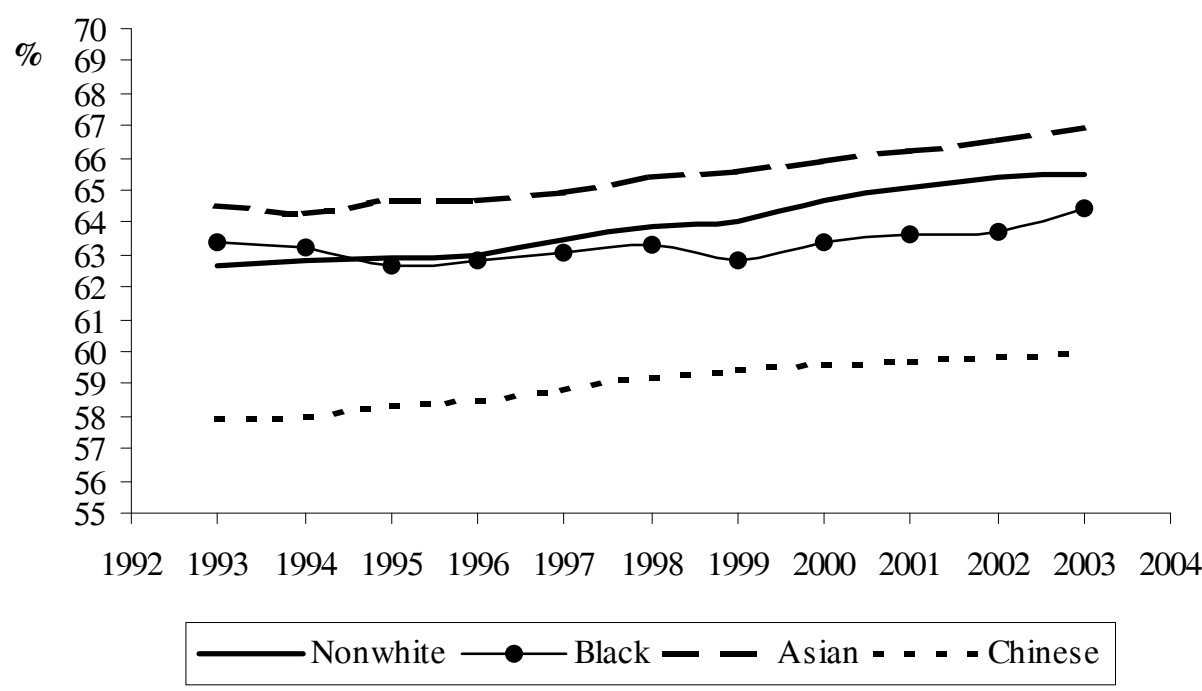

Figure 3. The evolution of ethnic population density over time

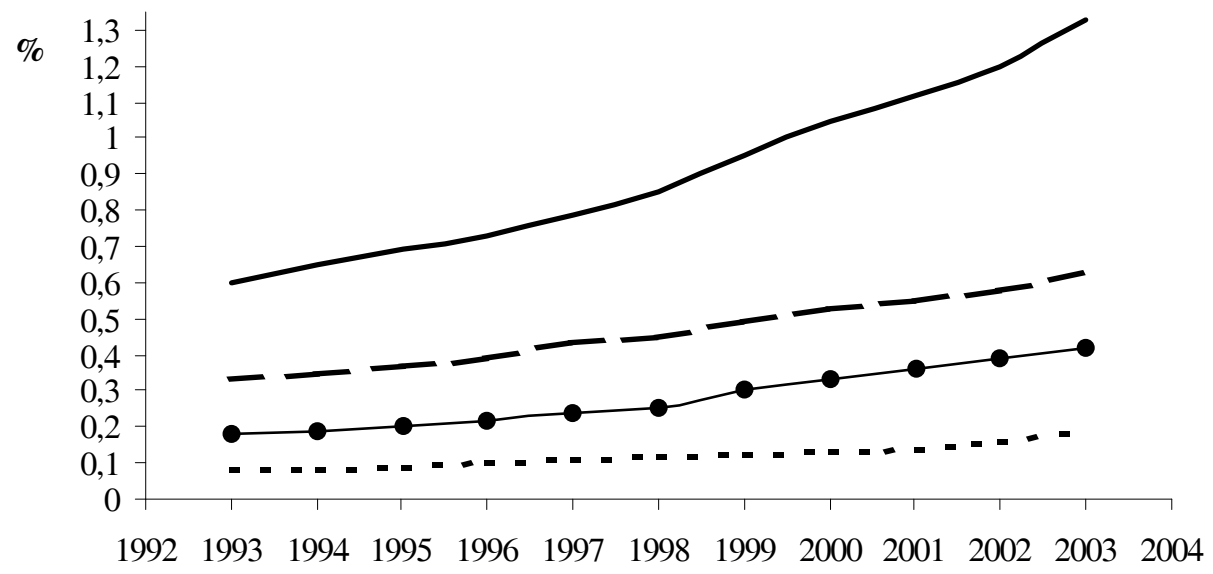

$\longrightarrow$ Nonwhite $\longrightarrow$ Black -- Asian - - - Chinese 
Figure 4. The evolution of ethnic self-employment over time

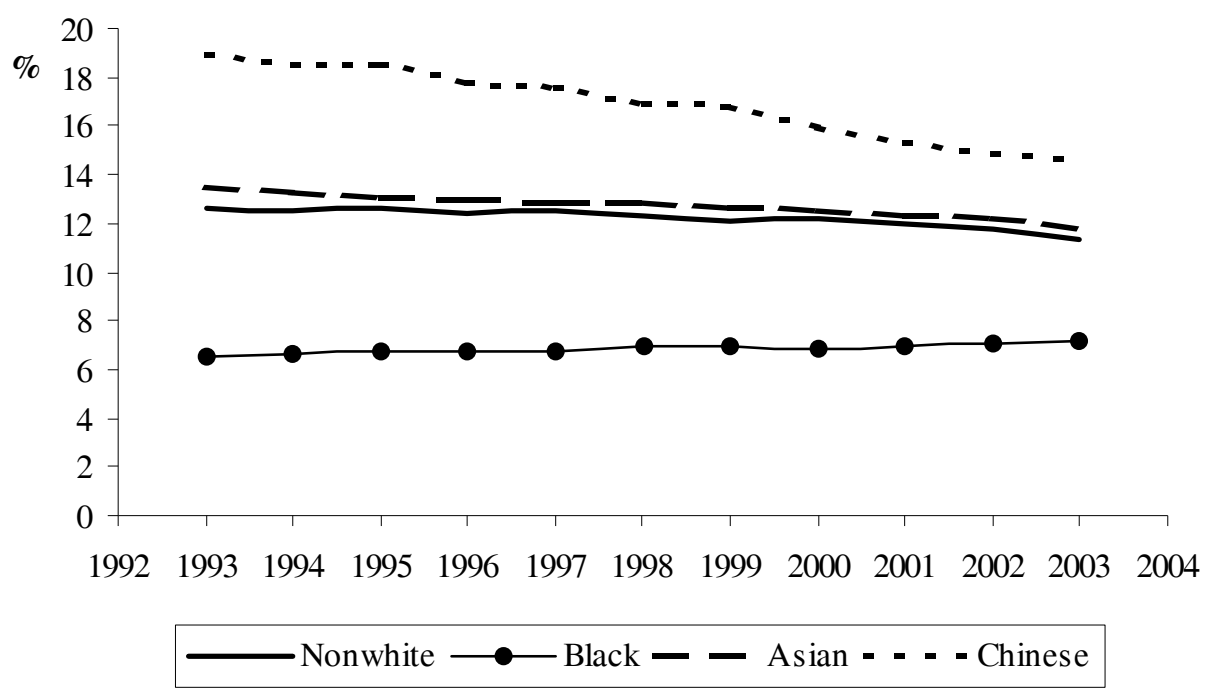


Table 1. Employment and population density by race

- OLS estimates -

\begin{tabular}{|c|c|c|c|c|c|c|c|c|}
\hline \multirow[b]{2}{*}{ Own ethnic group population density } & \multicolumn{2}{|l|}{ Whites } & \multicolumn{2}{|l|}{ Blacks } & \multicolumn{2}{|l|}{ Asians } & \multicolumn{2}{|l|}{ Chinese } \\
\hline & & & & & & & & \\
\hline ...within $30 \mathrm{~min}$ & $\begin{array}{l}0.0161 \\
(0.36)\end{array}$ & $\begin{array}{l}0.0125 \\
(0.75)\end{array}$ & $\begin{array}{l}0.0879 \\
(4.05)\end{array}$ & $\begin{array}{l}0.0958 \\
(4.69)\end{array}$ & $\begin{array}{l}0.0976 \\
(3.49)\end{array}$ & $\begin{array}{l}0.1005 \\
(3.01)\end{array}$ & $\begin{array}{l}0.0801 \\
(3.05)\end{array}$ & $\begin{array}{l}0.0859 \\
(3.15)\end{array}$ \\
\hline ... within 30-60 min & $\begin{array}{l}0.0205 \\
(0.88)\end{array}$ & $\begin{array}{l}0.0112 \\
(1.15)\end{array}$ & $\begin{array}{l}0.0325 \\
(3.89)\end{array}$ & $\begin{array}{l}0.0319 \\
(4.58)\end{array}$ & $\begin{array}{l}0.0250 \\
(4.46)\end{array}$ & $\begin{array}{l}0.0313 \\
(4.68)\end{array}$ & $\begin{array}{l}0.0259 \\
(3.67)\end{array}$ & $\begin{array}{l}0.0235 \\
(3.45)\end{array}$ \\
\hline ... within 60-90 min & $\begin{array}{l}0.0101 \\
(1.03)\end{array}$ & $\begin{array}{l}0.0090 \\
(0.99)\end{array}$ & $\begin{array}{l}0.0133 \\
(2.55)\end{array}$ & $\begin{array}{l}0.0101 \\
(2.75)\end{array}$ & $\begin{array}{l}0.0113 \\
(2.69)\end{array}$ & $\begin{array}{l}0.0099 \\
(2.58)\end{array}$ & $\begin{array}{l}0.0134 \\
(3.04)\end{array}$ & $\begin{array}{l}0.0068 \\
(2.98)\end{array}$ \\
\hline ... within 90-120 min & $\begin{array}{l}0.0044 \\
(0.29)\end{array}$ & $\begin{array}{l}0.0029 \\
(0.54)\end{array}$ & $\begin{array}{l}0.0079 \\
(1.09)\end{array}$ & $\begin{array}{l}0.0055 \\
(1.28)\end{array}$ & $\begin{array}{l}0.0027 \\
(0.75)\end{array}$ & $\begin{array}{l}0.0035 \\
(1.15)\end{array}$ & $\begin{array}{l}0.0059 \\
(0.49)\end{array}$ & $\begin{array}{l}0.0046 \\
(0.69)\end{array}$ \\
\hline$\ldots$ within $120-150 \mathrm{~min}$ & $\begin{array}{l}0.0017 \\
(0.15)\end{array}$ & $\begin{array}{l}0.0015 \\
(0.21)\end{array}$ & $\begin{array}{l}0.0085 \\
(0.44)\end{array}$ & $\begin{array}{l}0.0043 \\
(0.58)\end{array}$ & $\begin{array}{l}0.0004 \\
(0.51)\end{array}$ & $\begin{array}{l}0.0012 \\
(0.82)\end{array}$ & $\begin{array}{l}0.0019 \\
(0.18)\end{array}$ & $\begin{array}{l}0.0010 \\
(0.29)\end{array}$ \\
\hline Time lag of dependent variable & $\begin{array}{l}0.5819 \\
(6.25)\end{array}$ & $\begin{array}{l}0.5544 \\
(6.73)\end{array}$ & $\begin{array}{l}0.3343 \\
(7.25)\end{array}$ & $\begin{array}{l}0.3145 \\
(7.65)\end{array}$ & $\begin{array}{l}0.2412 \\
(5.02)\end{array}$ & $\begin{array}{l}0.2069 \\
(5.36)\end{array}$ & $\begin{array}{l}0.3908 \\
(6.29)\end{array}$ & $\begin{array}{l}0.3435 \\
(6.52)\end{array}$ \\
\hline Regional dummies & no & yes & no & yes & no & yes & no & yes \\
\hline R-squared & 0.3008 & 0.3890 & 0.7555 & 0.7890 & 0.7480 & 0.8207 & 0.7485 & 0.7905 \\
\hline
\end{tabular}

Notes:

Dependent variable: male employment rate by race group

The number of observations is 3,010 (301 area, 10 time periods) in all cases.

Within groups parameter estimates and $t$-ratios in parentheses are reported. 
Table 2. Employment and population density by race

- IV estimates -

\begin{tabular}{|c|c|c|c|c|}
\hline & Whites & Blacks & Asians & Chinese \\
\hline \multicolumn{5}{|l|}{ Own ethnic group population density } \\
\hline ...within 30 min & $\begin{array}{l}0.1570 \\
(1.15)\end{array}$ & $\begin{array}{l}0.1219 \\
(4.96)\end{array}$ & $\begin{array}{l}0.1402 \\
(3.99)\end{array}$ & $\begin{array}{l}0.1115 \\
(3.69)\end{array}$ \\
\hline ... within 30-60 min & $\begin{array}{l}0.1013 \\
(1.19)\end{array}$ & $\begin{array}{l}0.0453 \\
(5.50)\end{array}$ & $\begin{array}{l}0.0405 \\
(5.43)\end{array}$ & $\begin{array}{l}0.0365 \\
(3.76)\end{array}$ \\
\hline ... within 60-90 min & $\begin{array}{l}0.0089 \\
(0.94)\end{array}$ & $\begin{array}{l}0.0231 \\
(3.95)\end{array}$ & $\begin{array}{l}0.0121 \\
(2.79)\end{array}$ & $\begin{array}{l}0.0101 \\
(3.18)\end{array}$ \\
\hline$\ldots$ within $90-120 \mathrm{~min}$ & $\begin{array}{l}0.0045 \\
(0.79)\end{array}$ & $\begin{array}{l}0.0116 \\
(1.42)\end{array}$ & $\begin{array}{l}0.0059 \\
(1.19)\end{array}$ & $\begin{array}{l}0.0079 \\
(0.88)\end{array}$ \\
\hline ... within 120-150 min & $\begin{array}{l}0.0020 \\
(0.26)\end{array}$ & $\begin{array}{l}0.0059 \\
(0.53)\end{array}$ & $\begin{array}{l}0.0018 \\
(0.42)\end{array}$ & $\begin{array}{l}0.0021 \\
(0.33)\end{array}$ \\
\hline Time lag of dependent variable & $\begin{array}{l}0.6370 \\
(6.62)\end{array}$ & $\begin{array}{l}0.4925 \\
(7.87)\end{array}$ & $\begin{array}{l}0.4141 \\
(6.12)\end{array}$ & $\begin{array}{l}0.4557 \\
(6.88)\end{array}$ \\
\hline Regional dummies & yes & yes & yes & yes \\
\hline R-squared & 0.4971 & 0.7915 & 0.82675 & 0.8045 \\
\hline $\begin{array}{c}\text { Sargan test } \\
{[7]}\end{array}$ & $\begin{array}{l}3.1516 \\
(0.87)\end{array}$ & $\begin{array}{l}1.1515 \\
(0.99)\end{array}$ & $\begin{array}{l}2.5576 \\
(0.93)\end{array}$ & $\begin{array}{l}2.1412 \\
(0.95)\end{array}$ \\
\hline M_1 & $\begin{array}{l}-16.554 \\
(0.00)\end{array}$ & $\begin{array}{l}-10.365 \\
(0.00)\end{array}$ & $\begin{array}{l}-17.221 \\
(0.00)\end{array}$ & $\begin{array}{l}-9.910 \\
(0.00)\end{array}$ \\
\hline M_2 & $\begin{array}{l}1.2524 \\
(0.2104)\end{array}$ & $\begin{array}{l}-0.6068 \\
(0.5440)\end{array}$ & $\begin{array}{l}0.7456 \\
(0.4559)\end{array}$ & $\begin{array}{l}-1.1625 \\
(0.2450)\end{array}$ \\
\hline
\end{tabular}

Notes:

Dependent variable: male employment rate by race group

Instruments: 1961 population in the area within 30 kilometers; within 600 kilometers; within 90 kilometers; within 120 kilometers; within 150 kilometers; lagged values of the dependent variable up to (t-6); regional dummies.

The reported test statistics with the associated probability level in parentheses are the following ones.

Sargan test: Sargan test of overidentifying restrictions, distributed as a chi-squared with degrees of freedom (reported in squared brackets) given by the difference between the number of overidentifying restrictions and the number of parameters;

M_1 and M_2: tests for first-order and second-order serial correlation in the first-differenced residuals, distributed as N(0,1) under the null of no serial correlation.

Estimation using Ox version 3.0 (Doornik, 2001). 
Table 3. Self-Employment and population density by race

- OLS estimates -

\begin{tabular}{|c|c|c|c|c|c|c|c|c|}
\hline \multirow[b]{2}{*}{ Own ethnic group population density } & \multicolumn{2}{|l|}{ Whites } & \multicolumn{2}{|l|}{ Blacks } & \multicolumn{2}{|l|}{ Asians } & \multicolumn{2}{|l|}{ Chinese } \\
\hline & & & & & & & & \\
\hline ...within $30 \mathrm{~min}$ & $\begin{array}{l}0.0570 \\
(1.20)\end{array}$ & $\begin{array}{l}0.0391 \\
(0.97)\end{array}$ & $\begin{array}{l}0.0685 \\
(3.13)\end{array}$ & $\begin{array}{l}0.0495 \\
(2.99)\end{array}$ & $\begin{array}{l}0.0789 \\
(3.04)\end{array}$ & $\begin{array}{l}0.0625 \\
(3.02)\end{array}$ & $\begin{array}{l}0.0580 \\
(4.42)\end{array}$ & $\begin{array}{l}0.0609 \\
(4.63)\end{array}$ \\
\hline ... within 30-60 min & $\begin{array}{l}0.0401 \\
(1.01)\end{array}$ & $\begin{array}{l}0.0112 \\
(0.61)\end{array}$ & $\begin{array}{l}0.0312 \\
(2.89)\end{array}$ & $\begin{array}{l}0.0273 \\
(2.78)\end{array}$ & $\begin{array}{l}0.0204 \\
(2.94)\end{array}$ & $\begin{array}{l}0.0200 \\
(2.76)\end{array}$ & $\begin{array}{l}0.0205 \\
(3.86)\end{array}$ & $\begin{array}{l}0.0215 \\
(3.74)\end{array}$ \\
\hline ... within $60-90 \mathrm{~min}$ & $\begin{array}{l}0.0108 \\
(0.76)\end{array}$ & $\begin{array}{l}0.0069 \\
(0.69)\end{array}$ & $\begin{array}{l}0.0112 \\
(2.45)\end{array}$ & $\begin{array}{l}0.0091 \\
(2.39)\end{array}$ & $\begin{array}{l}0.0100 \\
(2.69)\end{array}$ & $\begin{array}{l}0.0109 \\
(2.47)\end{array}$ & $\begin{array}{l}0.0123 \\
(3.22)\end{array}$ & $\begin{array}{l}0.0065 \\
(3.09)\end{array}$ \\
\hline ... within 90-120 min & $\begin{array}{l}0.0049 \\
(0.57)\end{array}$ & $\begin{array}{l}0.0042 \\
(0.45)\end{array}$ & $\begin{array}{l}0.0055 \\
(0.92)\end{array}$ & $\begin{array}{l}0.0022 \\
(0.62)\end{array}$ & $\begin{array}{l}0.0020 \\
(0.55)\end{array}$ & $\begin{array}{l}0.0013 \\
(0.15)\end{array}$ & $\begin{array}{l}0.0045 \\
(0.64)\end{array}$ & $\begin{array}{l}0.0034 \\
(0.76)\end{array}$ \\
\hline$\ldots$ within $120-150$ min & $\begin{array}{l}0.0025 \\
(0.32)\end{array}$ & $\begin{array}{l}0.0021 \\
(0.20)\end{array}$ & $\begin{array}{l}0.0018 \\
(0.34)\end{array}$ & $\begin{array}{l}0.0009 \\
(0.26)\end{array}$ & $\begin{array}{l}0.0001 \\
(0.51)\end{array}$ & $\begin{array}{l}0.0012 \\
(0.82)\end{array}$ & $\begin{array}{l}0.0015 \\
(0.28)\end{array}$ & $\begin{array}{l}0.0008 \\
(0.39)\end{array}$ \\
\hline Time lag of dependent variable & $\begin{array}{l}0.4338 \\
(7.02)\end{array}$ & $\begin{array}{l}0.4032 \\
(7.12)\end{array}$ & $\begin{array}{l}0.3003 \\
(8.89)\end{array}$ & $\begin{array}{l}0.2834 \\
(7.96)\end{array}$ & $\begin{array}{l}0.1992 \\
(3.05)\end{array}$ & $\begin{array}{l}0.1720 \\
(2.89)\end{array}$ & $\begin{array}{l}0.4253 \\
(9.32)\end{array}$ & $\begin{array}{l}0.4493 \\
(9.95)\end{array}$ \\
\hline Regional dummies & no & yes & no & yes & no & yes & no & yes \\
\hline R-squared & 0.3445 & 0.4003 & 0.7223 & 0.7668 & 0.7334 & 0.7820 & 0.7744 & 0.8087 \\
\hline
\end{tabular}

Notes:

Dependent variable: male self-employment rate by race group

The number of observations is 3,010 (301 area, 10 time periods) in all cases.

Within groups parameter estimates and $t$-ratios in parentheses are reported. 
Table 4. Ethnic Employment and Self-employment by industry

\begin{tabular}{|c|c|c|c|c|c|c|c|c|c|c|c|c|}
\hline & \multicolumn{4}{|c|}{ Blacks } & \multicolumn{4}{|c|}{ Asians } & \multicolumn{4}{|c|}{ Chinese } \\
\hline & \multicolumn{2}{|c|}{ Employment } & \multicolumn{2}{|c|}{ Self-employed } & \multicolumn{2}{|c|}{ Employed } & \multicolumn{2}{|c|}{ Self-employed } & \multicolumn{2}{|l|}{ Employed } & \multicolumn{2}{|c|}{ Self-employed } \\
\hline & $\begin{array}{l}\text { Average } \\
2003 \\
\end{array}$ & $\begin{array}{l}\text { Change } \\
1993-2003\end{array}$ & $\begin{array}{l}\text { Average } \\
2003 \\
\end{array}$ & $\begin{array}{l}\text { Change } \\
1993-2003\end{array}$ & $\begin{array}{l}\text { Average } \\
2003\end{array}$ & $\begin{array}{l}\text { Change } \\
1993-2003\end{array}$ & $\begin{array}{l}\text { Average } \\
2003\end{array}$ & $\begin{array}{l}\text { Change } \\
1993-2003\end{array}$ & $\begin{array}{l}\text { Average } \\
2003 \\
\end{array}$ & $\begin{array}{l}\text { Change } \\
1993-2003\end{array}$ & $\begin{array}{l}\text { Average } \\
2003\end{array}$ & $\begin{array}{l}\text { Change } \\
1993-2003\end{array}$ \\
\hline Agriculture \& Fishing & 0.2 & -1 & 0.4 & +1 & 1.3 & -0.5 & 0.9 & -3 & 0.1 & 0 & 1.8 & -2 \\
\hline Manufacturing \& Costruction & 15.9 & -1 & 25.1 & +3 & 14.8 & -1 & 7.3 & +3 & 7.1 & +2 & 8.7 & +5 \\
\hline $\begin{array}{l}\text { Distribution, hotels \& } \\
\text { restaurants }\end{array}$ & 20.9 & +2 & 20.2 & -7 & 47.3 & +4 & 40.4 & -9 & 52.7 & +5 & 71.4 & -10 \\
\hline Transport \& communication & 13.2 & -3 & 12.4 & -1 & 15.9 & +1 & 17.3 & +8 & 6.8 & -1 & 3.5 & +0.6 \\
\hline Banking, finance \& insurance & 21.3 & +7 & 21.5 & +12 & 10.7 & +6 & 9.4 & +4 & 15.9 & +5 & 8.4 & +4 \\
\hline Other & 28.5 & +1 & 20.4 & -5 & 10.0 & -2 & 8.2 & -4 & 17.4 & -2 & 6.2 & -2 \\
\hline Total & 100 & & 100 & & 100 & & & & 100 & & 100 & \\
\hline
\end{tabular}


Table 5. Employment and population density by race and industry - OLS estimates -

\begin{tabular}{|c|c|c|c|c|c|c|c|c|c|c|c|c|}
\hline & \multicolumn{2}{|c|}{ Agriculture \& Fishing } & \multicolumn{2}{|c|}{$\begin{array}{l}\text { Manufacturing \& } \\
\text { Costruction }\end{array}$} & \multicolumn{2}{|c|}{$\begin{array}{c}\text { Distribution, hotels \& } \\
\text { restaurants }\end{array}$} & \multicolumn{2}{|c|}{$\begin{array}{c}\text { Transport \& } \\
\text { communication }\end{array}$} & \multicolumn{2}{|c|}{$\begin{array}{c}\text { Banking, finance \& } \\
\text { insurance }\end{array}$} & \multirow{2}{*}{$\begin{array}{c}\text { Other } \\
\text { Whites }\end{array}$} & \multirow[b]{2}{*}{ Nonwhites } \\
\hline & Whites & Nonwhites & Whites & Nonwhites & Whites & Nonwhites & Whites & Nonwhites & Whites & Nonwhites & & \\
\hline ...within 30 min & $\begin{array}{l}0.0250 \\
(1.25)\end{array}$ & $\begin{array}{l}0.0191 \\
(2.07)\end{array}$ & $\begin{array}{l}0.0187 \\
(0.95)\end{array}$ & $\begin{array}{l}0.0685 \\
(3.13)\end{array}$ & $\begin{array}{l}0.0497 \\
(0.48)\end{array}$ & $\begin{array}{l}0.0989 \\
(3.65)\end{array}$ & $\begin{array}{l}0.0158 \\
(0.69)\end{array}$ & $\begin{array}{l}0.0399 \\
(2.99)\end{array}$ & $\begin{array}{l}0.0674 \\
(1.34)\end{array}$ & $\begin{array}{l}0.0562 \\
(3.15)\end{array}$ & $\begin{array}{l}0.0258 \\
(1.42)\end{array}$ & $\begin{array}{l}0.0460 \\
(3.56)\end{array}$ \\
\hline$\ldots$ within $60-90 \mathrm{~min}$ & $\begin{array}{l}0.0119 \\
(0.97)\end{array}$ & $\begin{array}{l}0.0069 \\
(0.68)\end{array}$ & $\begin{array}{l}0.0091 \\
(0.68)\end{array}$ & $\begin{array}{l}0.0100 \\
(2.45)\end{array}$ & $\begin{array}{l}0.0119 \\
(0.16)\end{array}$ & $\begin{array}{l}0.0205 \\
(1.18)\end{array}$ & $\begin{array}{l}0.0102 \\
(0.27)\end{array}$ & $\begin{array}{l}0.0109 \\
(2.03)\end{array}$ & $\begin{array}{l}0.0210 \\
(1.00)\end{array}$ & $\begin{array}{l}0.0159 \\
(2.49)\end{array}$ & $\begin{array}{l}0.0091 \\
(0.52)\end{array}$ & $\begin{array}{l}0.0096 \\
(2.07)\end{array}$ \\
\hline$\ldots$ within $90-120$ min & $\begin{array}{l}0.0084 \\
(0.55)\end{array}$ & $\begin{array}{l}0.0034 \\
(0.45)\end{array}$ & $\begin{array}{l}0.0033 \\
(0.20)\end{array}$ & $\begin{array}{l}0.0055 \\
(0.92)\end{array}$ & $\begin{array}{l}0.0101 \\
(0.05)\end{array}$ & $\begin{array}{l}0.0103 \\
(1.01)\end{array}$ & $\begin{array}{l}0.0065 \\
(0.28)\end{array}$ & $\begin{array}{l}0.0072 \\
(1.02)\end{array}$ & $\begin{array}{l}0.0120 \\
(0.51)\end{array}$ & $\begin{array}{l}0.0097 \\
(2.15)\end{array}$ & $\begin{array}{l}0.0045 \\
(0.16)\end{array}$ & $\begin{array}{l}0.0031 \\
(0.79)\end{array}$ \\
\hline ... within $120-150$ min & $\begin{array}{l}0.0052 \\
(0.31)\end{array}$ & $\begin{array}{l}0.0021 \\
(0.20)\end{array}$ & $\begin{array}{l}0.0055 \\
(0.44)\end{array}$ & $\begin{array}{l}0.0018 \\
(0.34)\end{array}$ & $\begin{array}{l}0.0060 \\
(0.01)\end{array}$ & $\begin{array}{l}0.0068 \\
(0.43)\end{array}$ & $\begin{array}{l}0.0041 \\
(0.15)\end{array}$ & $\begin{array}{l}0.0019 \\
(0.62)\end{array}$ & $\begin{array}{l}0.0076 \\
(0.35)\end{array}$ & $\begin{array}{l}0.0015 \\
(0.83)\end{array}$ & $\begin{array}{l}0.0015 \\
(0.12)\end{array}$ & $\begin{array}{l}0.0010 \\
(0.23)\end{array}$ \\
\hline Time lag of dependent variable & $\begin{array}{l}0.4355 \\
(4.05)\end{array}$ & $\begin{array}{l}0.4110 \\
(3.12)\end{array}$ & $\begin{array}{l}0.4993 \\
(7.05)\end{array}$ & $\begin{array}{l}0.4300 \\
(6.68)\end{array}$ & $\begin{array}{l}0.5524 \\
(5.02)\end{array}$ & $\begin{array}{l}0.2306 \\
(5.36)\end{array}$ & $\begin{array}{l}0.3145 \\
(7.65)\end{array}$ & $\begin{array}{l}0.3283 \\
(2.95)\end{array}$ & $\begin{array}{l}0.2199 \\
(3.90)\end{array}$ & $\begin{array}{l}0.1872 \\
(2.85)\end{array}$ & $\begin{array}{l}0.4253 \\
(8.83)\end{array}$ & $\begin{array}{l}0.2446 \\
(4.95)\end{array}$ \\
\hline Regional dummies & no & yes & no & no & no & yes & yes & yes & no & yes & no & yes \\
\hline R-squared & 0.3004 & 0.7500 & 0.2755 & 0.7622 & 0.2537 & 0.8212 & 0.2478 & 0.7619 & 0.3273 & 0.7855 & 0.3277 & 0.7580 \\
\hline
\end{tabular}

Dependent variable: employment rate by race group

The number of observations is 3,010 (301 area, 10 time periods) in all cases.

Within groups parameter estimates and $t$-ratios in parentheses are reported. 
Table 6. Employment and population density by race: Female only

- OLS estimates -

\begin{tabular}{|c|c|c|c|c|c|c|c|c|}
\hline \multirow[b]{2}{*}{ Own ethnic group population density } & \multicolumn{2}{|l|}{ Whites } & \multicolumn{2}{|l|}{ Blacks } & \multicolumn{2}{|l|}{ Asians } & \multicolumn{2}{|l|}{ Chinese } \\
\hline & & & & & & & & \\
\hline ...within 30 min & $\begin{array}{l}0.1058 \\
(1.32)\end{array}$ & $\begin{array}{l}0.0631 \\
(0.109)\end{array}$ & $\begin{array}{l}0.0468 \\
(1.43)\end{array}$ & $\begin{array}{l}0.0345 \\
(1.18)\end{array}$ & $\begin{array}{l}0.0337 \\
(1.22)\end{array}$ & $\begin{array}{l}0.0325 \\
(1.52)\end{array}$ & $\begin{array}{l}0.0568 \\
(1.34)\end{array}$ & $\begin{array}{l}0.0608 \\
(1.56)\end{array}$ \\
\hline ... within 30-60 min & $\begin{array}{l}0.0640 \\
(1.15)\end{array}$ & $\begin{array}{l}0.0421 \\
(0.101)\end{array}$ & $\begin{array}{l}0.0321 \\
(1.08)\end{array}$ & $\begin{array}{l}0.0192 \\
(0.97)\end{array}$ & $\begin{array}{l}0.0210 \\
(1.14)\end{array}$ & $\begin{array}{l}0.0201 \\
(1.35)\end{array}$ & $\begin{array}{l}0.0267 \\
(0.86)\end{array}$ & $\begin{array}{l}0.0231 \\
(0.96)\end{array}$ \\
\hline ... within 60-90 min & $\begin{array}{l}0.0228 \\
(0.97)\end{array}$ & $\begin{array}{l}0.0206 \\
(0.65)\end{array}$ & $\begin{array}{l}0.0101 \\
(0.45)\end{array}$ & $\begin{array}{l}0.0090 \\
(0.39)\end{array}$ & $\begin{array}{l}0.0095 \\
(1.06)\end{array}$ & $\begin{array}{l}0.0088 \\
(1.07)\end{array}$ & $\begin{array}{l}0.0102 \\
(0.72)\end{array}$ & $\begin{array}{l}0.0076 \\
(0.70)\end{array}$ \\
\hline ... within 90-120 min & $\begin{array}{l}0.0104 \\
(0.75)\end{array}$ & $\begin{array}{l}0.0054 \\
(0.45)\end{array}$ & $\begin{array}{l}0.0065 \\
(0.39)\end{array}$ & $\begin{array}{l}0.0042 \\
(0.32)\end{array}$ & $\begin{array}{l}0.0028 \\
(0.55)\end{array}$ & $\begin{array}{l}0.0025 \\
(0.56)\end{array}$ & $\begin{array}{l}0.0054 \\
(0.69)\end{array}$ & $\begin{array}{l}0.0037 \\
(0.60)\end{array}$ \\
\hline ... within 120-150 min & $\begin{array}{l}0.0099 \\
(0.55)\end{array}$ & $\begin{array}{l}0.0032 \\
(0.32)\end{array}$ & $\begin{array}{l}0.0021 \\
(0.31)\end{array}$ & $\begin{array}{l}0.0030 \\
(0.28)\end{array}$ & $\begin{array}{l}0.0011 \\
(0.35)\end{array}$ & $\begin{array}{l}0.0008 \\
(0.40)\end{array}$ & $\begin{array}{l}0.0019 \\
(0.29)\end{array}$ & $\begin{array}{l}0.0009 \\
(0.14)\end{array}$ \\
\hline Time lag of dependent variable & $\begin{array}{l}0.5543 \\
(9.10)\end{array}$ & $\begin{array}{l}0.4603 \\
(8.71)\end{array}$ & $\begin{array}{l}0.3550 \\
(7.85)\end{array}$ & $\begin{array}{l}0.3238 \\
(7.19)\end{array}$ & $\begin{array}{l}0.2021 \\
(3.01)\end{array}$ & $\begin{array}{l}0.2172 \\
(3.20)\end{array}$ & $\begin{array}{l}0.4025 \\
(6.63)\end{array}$ & $\begin{array}{l}0.3845 \\
(6.96)\end{array}$ \\
\hline Regional dummies & no & yes & no & yes & no & yes & no & yes \\
\hline R-squared & 0.3741 & 0.4273 & 0.6422 & 0.6565 & 0.6173 & 0.6415 & 0.6274 & 0.6500 \\
\hline
\end{tabular}

Notes:

Dependent variable: female employment rate by race group

The number of observations is 3,010 (301 area, 10 time periods) in all cases.

Within groups parameter estimates and $t$-ratios in parentheses are reported. 